Article

\title{
Enzymatic Synthesis of $\omega$-Hydroxydodecanoic Acid By Employing a Cytochrome P450 from Limnobacter sp. 105 MED
}

\author{
Sung-Yeon Joo ${ }^{1,+}$, Hee-Wang Yoo ${ }^{2,+}$, Sharad Sarak ${ }^{3}$, Byung-Gee Kim ${ }^{1,2, *}$ and Hyungdon Yun ${ }^{3, *}$ \\ 1 School of Chemical and Biological Engineering, Seoul National University, Seoul 08826, Korea; \\ celberose@gmail.com \\ 2 Bioengineering Institute, Seoul National University, Seoul 08826, Korea; wsiy@naver.com \\ 3 Department of Systems Biotechnology, Konkuk University, Seoul 05029, Korea; sharad.niper2014@gmail.com \\ * Correspondence: byungkim@snu.ac.kr (B.-G.K.); hyungdon@konkuk.ac.kr (H.Y.) \\ + These authors contributed equally to this work.
}

Received: 12 December 2018; Accepted: 3 January 2019; Published: 8 January 2019

check for updates

\begin{abstract}
Hydroxylated fatty acids are valuable and versatile building blocks for the production of various adhesives, lubricants, cosmetic intermediates, etc. The biosynthesis of $\omega$-hydroxydodecanoic acid from vegetable oils is one of the important green pathways for their chemical-based synthesis. In the present study, the novel monooxygenase CYP153AL.m from Limnobacter sp. 105 MED was used for the whole-cell biotransformations. We constructed three-component system that was comprised of CYP153AL.m, putidaredoxin and putidaredoxin reductase from Pseudomonas putida. This in vivo study demonstrated that CYP153AL.m is a powerful catalyst for the biosynthesis of $\omega$-hydroxydodecanoic acid. Under optimized conditions, the application of a solid-state powdered substrate rather than a substrate dissolved in DMSO significantly enhanced the overall reaction titer of the process. By employing this efficient system, $2 \mathrm{~g} / \mathrm{L}$ of 12-hydroxydodecanoic acid (12-OHDDA) was produced from $4 \mathrm{~g} / \mathrm{L}$ of its corresponding fatty acid, which was namely dodecanoic acid. Furthermore, the system was extended to produce $3.28 \mathrm{~g} / \mathrm{L}$ of 12-OHDDA using $4 \mathrm{~g} / \mathrm{L}$ of substrate by introducing native redox partners. These results demonstrate the utility of CYP153AL.m-catalyzed biotransformations in the industrial production of 12-OHDDA and other valuable building blocks.
\end{abstract}

Keywords: 12-hydroxydodecanoic acid; dodecanoic acid; CYP153A; whole-cell biotransformation

\section{Introduction}

$\omega$-Hydroxylated fatty acids ( $\omega$-OHFAs) obtained from medium- and long-chain length fatty acids are versatile building blocks that are used as precursors for bioplastics [1] and high-end polymers in the chemical industry [2,3]. In addition, oxygenated fatty acids can be used in the cosmetics industry to produce perfumes and for pharmaceutical applications as anticancer agents and polyketide antibiotics $[4,5]$. To synthesize $\omega$-OHFAs, various chemical routes have been reported, including cross-metathesis of unsaturated fatty acid esters, followed by the hydroformylation and hydrogenation of the carbonyl group [6] or by the reduction of $\alpha, \omega$-dicarboxylic acids [7]. However, the chemical-based processes for the oxidation of the unreactive carbon atom require very harsh conditions and multiple steps; depend on nonrenewable feedstocks and have poor selectivity [8].

For these reasons, attention has been focused on biological approaches. Wenhua $\mathrm{Lu}$ and co-workers have reported biotransformation of $200 \mathrm{~g} / \mathrm{L}$ methyl tetradecanoate, which resulted into $174 \mathrm{~g} / \mathrm{L}$ and $6 \mathrm{~g} / \mathrm{L}$ of its corresponding OHFAs and $\alpha, \omega$-dicarboxylic acids ( $\omega$-DCAs), respectively, using an engineered Candida tropicalis [9]. Although remarkable progress has been made, these 
production platforms have not been exploited to a larger extent yet. Factors affecting the applicability of these processes for the large-scale production include low productivity, instability of biocatalyst and the requirement of economically feasible production facilities [10].

To overcome these limitations, alternative bacterial-based processes have been investigated. In these processes, the main key enzyme is CYP153As. The CYP153s are bacterial class I P450 enzymes that operate as three-component systems, containing a heme-dependent monooxygenase core (CYP) and two additional redox partners and/or domains, which are namely an iron-sulfur electron carrier (ferredoxin, Fdx) and a FAD-containing reductase (ferredoxin reductase, FdR). These transfer electrons from $\mathrm{NAD}(\mathrm{P}) \mathrm{H}$ to the monooxygenase active site [11]. This subfamily displays excellent activity towards the $\omega$-hydroxylation of alkanes, primary alcohols and fatty acids [12].

Recently, Bernhard Hauer and co-workers have demonstrated the construction of a chimeric protein, where the heme domain of CYP153AM.aq. was fused to the reductase domain of CYP102A1 isolated from Bacillus megaterium (B. megaterium) ( $\mathrm{CPR}_{\mathrm{BM} 3}$ ), the most catalytically active $\mathrm{P} 450$ reported to date [13]. Additionally, they introduced the G307A mutant based on the GGNDT motif in the I-helix, conserved in CYP153A subfamily, which showed 2- to 20-fold increase in the activity toward medium chain fatty acids [14].

The CYP153A.M. aq.-CPR $\mathrm{BM}_{3}$ fusion construct has been used for in vivo hydroxylation to produce $\omega$-OHDDA. This reaction produced $1.2 \mathrm{~g} / \mathrm{L}$ of $\omega$-hydroxydodecanoic acid ( $\omega$-OHDDA) with high regioselectivity ( $>95 \% \omega$-regioselectivity) for the terminal position by using $10 \mathrm{~g} / \mathrm{L}$ of its corresponding free fatty acid as a substrate [10]. However, feasible productivity and yield at an industrial scale have not been reached yet. In the current study, an enzyme mining approach revealed that an excellent CYP153A can be a powerful catalyst in the three-component systems. During this study, the application of a solid-state powdered substrate rather than a substrate dissolved in DMSO and introducing the native redox partner were shown to be effective strategies (Figure 1).

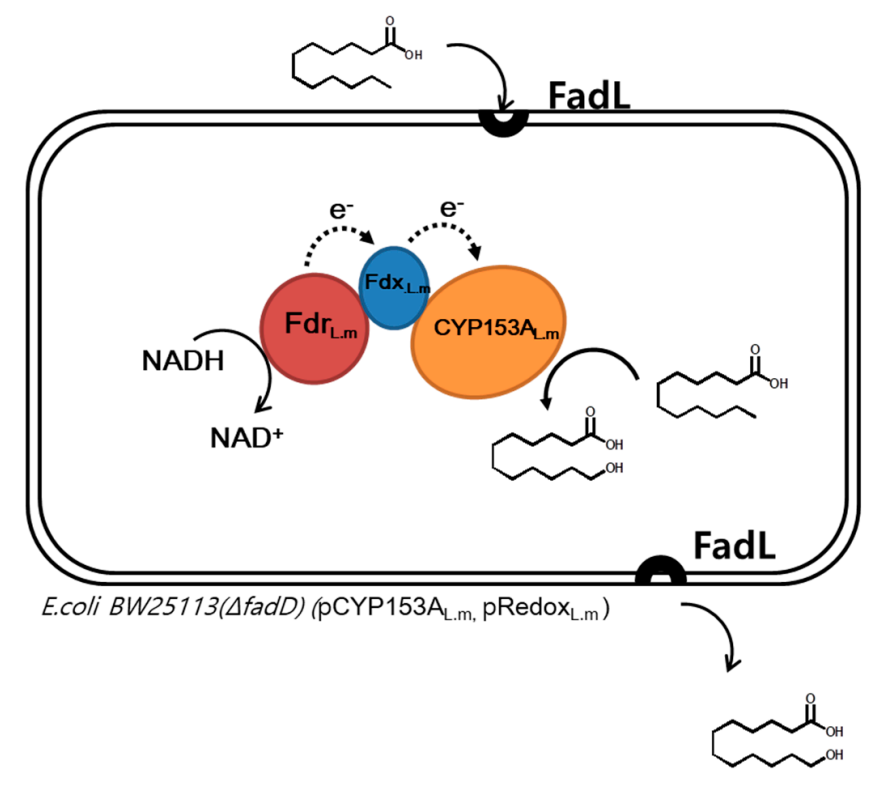

Figure 1. Synthesis of $\omega$-hydroxydodecanoic acid ( $\omega$-OHDDA) from dodecanoic acid (DDA) using CYP153A three-component system.

\section{Results and Discussion}

\subsection{Construction of a CYP153A Three-Component System}

Bioinformatic tools have been routinely used to search for new enzymes and for conducting analysis of the similarity among already available enzymes [15-17]. Previously, the CYP153A from Marinobacter aquaeolei (CYP153AM.aq.) was reported to possess high activity and selectivity toward 
$\omega$-hydroxylation of C12-FA (63\% conversion, 95\% $\omega$-regioselectivity) [14]. For the identification of more suitable CYP153As, Basic Local Alignment Search Tool (BLAST) search was performed using CYP153AM.aq as a query sequence and 100 candidates showing resemblance to the query sequence were selected. Among them, seven CYP153As were randomly selected from various groups based on a phylogenetic tree (Figure S1). The genes encoding CYP153As were cloned into pCDF_duet vector and expressed in E. coli BW25113 $\triangle \mathrm{fadD}$ (DE3). As CYP153As from Oceanococcus atlanticus, Alcanivorax jadensis T9 and Nocardioides luteus (CYP53AO.a, CYP153AA.j and CYP153AN.l, respectively) were expressed as inclusion bodies, they were neglected in the further studies. SDS-PAGE analysis and CO-binding assays confirmed the production of the other three CYP153As in soluble and active forms (Figures S2 and S3).

To compare the performance of the active P450s, whole-cell $\left(0.11 \mathrm{~g}_{\mathrm{CDW}} / \mathrm{mL}\right)$ reactions were carried out at $30^{\circ} \mathrm{C}$ and $200 \mathrm{rpm}$ using cells with the active P450s, which co-expressed CamA (putidaredoxin reductase) and CamB (putidaredoxin) from Pseudomonas putida in potassium phosphate buffer $(100 \mathrm{mM}$, $\mathrm{pH} 7.5)$ in the presence of $1 \%(w / v)$ glucose. The Cells with CYP153AA.d from Alcanivorax dieselolei produced the lowest $\omega$-OHDDA $(0.38 \mathrm{~g} / \mathrm{L})$ in $24 \mathrm{~h}$, while those of CYP153AS.f from Solimonas flava and CYP153AM.aq produced $0.72 \mathrm{~g} / \mathrm{L}$ and $1.13 \mathrm{~g} / \mathrm{L}$ from $4 \mathrm{~g} / \mathrm{L}$ of DDA (Figure 2a).

a

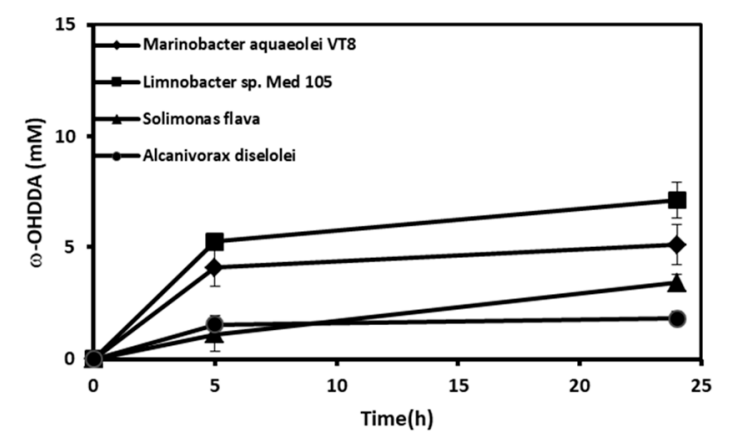

b

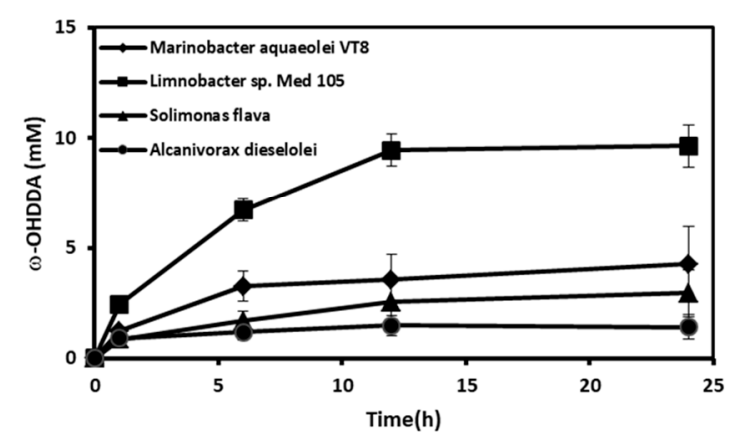

Figure 2. $\omega$-Hydroxylation of $20 \mathrm{mM}$ DDA by CYP153A and Cam AB containing cells, Reaction conditions: Volume, $10 \mathrm{~mL}$ in $100 \mathrm{~mL}$ flask; Temp, $30{ }^{\circ} \mathrm{C}$; Cell type, BW25113 $(\Delta \mathrm{fadD}$, DE3) with CYP153AM.aq, CYP153AL.m, CYP153AS.f and CYP153AA.d, respectively, with CamA/B; Cell OD600, 30; Phosphate buffer, 100 mM; pH, 7.5; glucose 1\% (w/v). (a) 20 mM DDA (DMSO 1\%), (b) $20 \mathrm{mM}$ of solid state powdered substrate.

The performance of CYP153AM.aq expressing cells was similar to that of the CYP153A.M. aq.-CPR $\mathrm{BM}_{3}$ fusion construct [10]. Furthermore, those with CYP153AL.m showed the largest $\omega$-OHDDA production (1.5 g/L) from $4 \mathrm{~g} / \mathrm{L}$ of DDA (Figure 2a). Interestingly, the yields achieved herein are the highest via batch reaction so far to best of our knowledge. We also attempted to make a more detailed comparison and determined the concentration of the active P450s by CO-binding assay (Figure S4). After normalization by the amount of active P450s, CYP153AL.m was shown to be more active than the other P450s (Figure S5). Therefore, through the enzyme mining approach, the CYP153AL.m containing three-component system was identified as an efficient catalyst for the bioconversion of DDA to $\omega$-OHDDA.

\subsection{Use of Solid State Powdered Substrate in Bioconversion}

In many cases, substrates for reactions catalyzed by $\mathrm{P} 450$ have limited water solubility. For example, medium chain fatty acids $\left(C_{10}-C_{16}\right)$ are water soluble from $\sim 7 \mathrm{mg} / \mathrm{L}$ to $61 \mathrm{mg} / \mathrm{L}$. Moreover, to increase the industrial feasibility of the process, two-liquid phase systems have been previously utilized by Maurer et al. [18] and von Buhler et al. [19]. Furthermore, the addition of co-solvents or cyclodextrins was reported by Donova et al. [20] and Kuehnel et al. [21]. However, the excessive use of DMSO as a co-solvent could damage the catalyst and host cell [22]. Moreover, 
Lundemo and co-workers demonstrated that a DMSO free strategy was advantageous in whole-cell P450 catalyzed reactions [23].

Based on these previous reports, cells were subjected to resting cell reaction in the absence of DMSO. The CYP153AL.m expressing strain was shown to give the highest yields in the conversion of DDA (4 g/L) to $\omega$-OHDDA (2 g/L), whereas CYP153AM.aq, CYP153AS.f and CYP153AA.d gave $0.9 \mathrm{~g} / \mathrm{L}, 0.63 \mathrm{~g} / \mathrm{L}$ and $0.3 \mathrm{~g} / \mathrm{L}$, respectively (Figure $2 \mathrm{~b}$ ). There is no significant difference in the amount of product obtained using a solid-state powdered substrate or a substrate dissolved in DMSO. The use of substrate in the solid state appeared to have a negligible effect on CYP153AM.aq, CYP153A.d and CYP153AS.f, having showed a slightly declined amount of conversion. Nevertheless, only the CYP153A.Lm-catalyzed reaction titer was shown to be improved using powdered substrate. Any efficient biocatalytic conversion requisites the effective uptake of the substrate followed by its conversion to the desired product $[24,25]$. The better uptake of a powdered substrate in the absence of DMSO could be the plausible reason for the better titer achieved by the cells expressing CYP153A.Lm.

\subsection{Effect of Homogeneous Redox Partners}

Generally, it has been accepted that the optimal redox partners for a P450 enzyme should be homogeneous ones [26-28]. Therefore, we tried to introduce native redox partners of Limnobacter sp. 105 MED. Using the functional protein association network database STRING v10.5 [29], a network comprising CYP153AL.m was obtained and we found that there are two Fdxs and one FdR from Limnobacter sp. 105 MED (Figure S6). The FdR (LimA) and a Fdx (LimB) with high values were codon-optimized and synthesized into pETduet_vector. After this, they were expressed and purified together with CYP153AL.m, CYP153AM.aq and CamA/B (Figure S7).

To evaluate the native redox partner chains, in vitro biotransformation was carried out with a final volume of $0.5 \mathrm{~mL}$ of $100 \mathrm{mM}$ potassium phosphate buffer ( $\mathrm{pH} 7.5$ ), containing $2 \mu \mathrm{M} \mathrm{CYP153A}$, ferredoxin reductase and ferredoxin (1:10:5 ratio). DDA was added at a final concentration of $0.5 \mathrm{mM}$ ( $25 \mathrm{mM}$ stock in DMSO). The reaction was started by the addition of $0.2 \mathrm{mM} \mathrm{NADH}$ and the coupling efficiencies were obtained by determining the ratio of the initial product forming rate and the NADH consumption rate as previously described [30].

Although the coupling efficiencies of CYPs are similar regardless of redox partners, the CYP153AL.m has a higher initial product forming rate $(8.91 \pm 0.89 \mu \mathrm{M} / \mathrm{min})$ than CYP153AM.aq $(7.41 \pm 0.70 \mu \mathrm{M} / \mathrm{min})$ and a higher NADH consumption than CYP153AM.aq $(17.04 \pm 0.32 \mu \mathrm{M} / \mathrm{min}$ and $13.83 \pm 1.16 \mu \mathrm{M} / \mathrm{min}$, respectively). Moreover, the native redox partners of CYP153A.L.m improved the performance with the highest initial product forming rate $(9.81 \pm 1.60 \mu \mathrm{M} / \mathrm{min})$ and the highest NADH consumption (20.26 $\pm 0.57 \mu \mathrm{M} / \mathrm{min})$ (Table 1).

Table 1. In vitro evaluation of native redox partners of CYP153AL.m.

\begin{tabular}{cccc}
\hline Entry & CYP153AM.aq CamA + CamB & CYP153AL.m CamA + CamB & CYP153AL.m LimA + LimB \\
\hline Coupling efficiency $(\%)$ & $53.6 \pm 5.5$ & $52.3 \pm 3.6$ & $48.4 \pm 5.4$ \\
Initial product forming rate $(\mu \mathrm{M} / \mathrm{min})$ & $7.41 \pm 0.70$ & $8.91 \pm 0.89$ & $9.81 \pm 1.60$ \\
NADH consumption rate $(\mu \mathrm{M} / \mathrm{min})$ & $13.83 \pm 1.16$ & $17.04 \pm 0.32$ & $20.26 \pm 0.57$ \\
\hline
\end{tabular}

After confirming the performance of the native redox partner chain, the proteins of the redox partner chain were further investigated in vivo. Whole-cell $\left(0.11 \mathrm{~g}_{\mathrm{CDW}} / \mathrm{mL}\right)$ reactions were carried out at $30^{\circ} \mathrm{C}$ and $200 \mathrm{rpm}$ using cells with CYP153A.L.m, co-expressing LimA and LimB in potassium phosphate buffer $(100 \mathrm{mM}, \mathrm{pH} 7.5)$ in the presence of $1 \%(w / v)$ glucose. Ideally, the in vivo endogenous three-component system produced $3.28 \mathrm{~g} / \mathrm{L}$ of 12-OHDDA from $4 \mathrm{~g} / \mathrm{L}$ DDA (Figure 3). Therefore, our data demonstrated that the application of naturally occurring redox partners can enhance the reactivity in vivo and in vitro. 


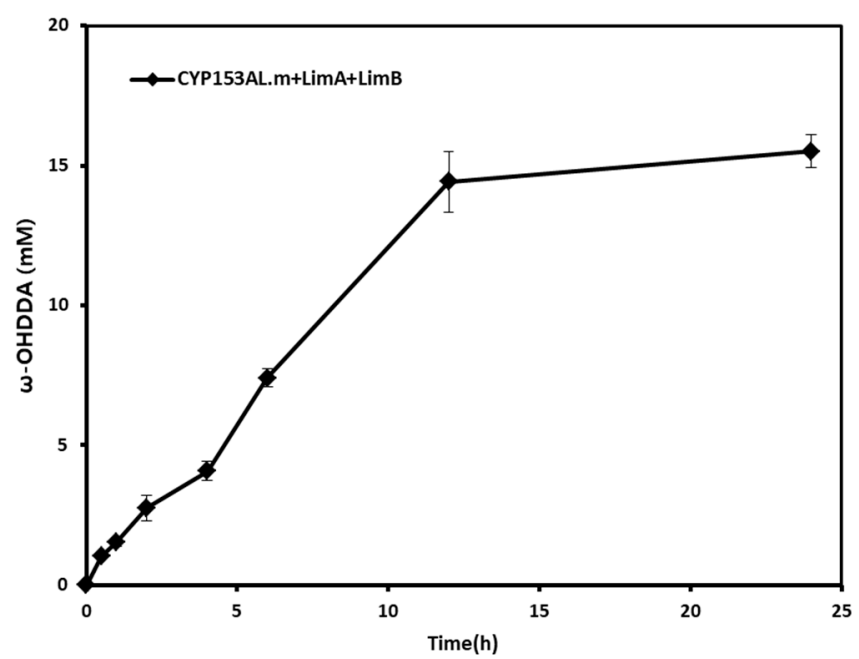

Figure 3. $\omega$-Hydroxylation of $20 \mathrm{mM}$ DDA by CYP153AL.m and LimAB containing cells. Reaction conditions: Substrate concentration, $20 \mathrm{mM}$; Volume, $10 \mathrm{~mL}$ in $100 \mathrm{~mL}$ flask; Temp, $30{ }^{\circ} \mathrm{C}$; Cell type, BW25113 ( $\triangle$ fadD, DE3) expressing CYP153AL.m and Lim A/B; Cell OD600, 30; Phosphate buffer, $100 \mathrm{mM} ; \mathrm{pH}, 7.5$; glucose $1 \%(w / v)$.

\subsection{Limitations of the CYP153AL Three-Component System}

The stability issues of CYPs have been frequently mentioned, which are caused by uncoupling of the NADH oxidation during product formation [23,31]. To evaluate the stability of our system, a series of four rounds was carried out with whole cells expressing CYP153AL.m and Cam A/B. In each round, the cells were purified and reused every $6 \mathrm{~h}$ in the next round as equilibrium is reached in a relatively short time period of $6 \mathrm{~h}$ (Figure $2 \mathrm{~b}$ ). In the second round, the amount of product obtained from the whole cells was considerably reduced (53\%) compared to the first round and further decreased to $35 \%$ in the third round (Figure 4a). This data implies that our system suffered from instability and thus, a relatively short process time is desirable.

a

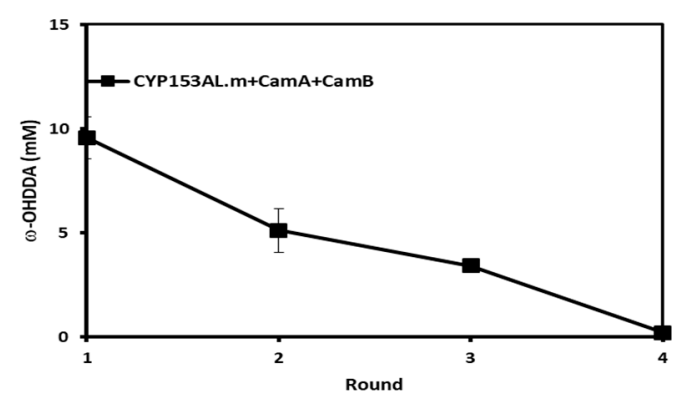

b

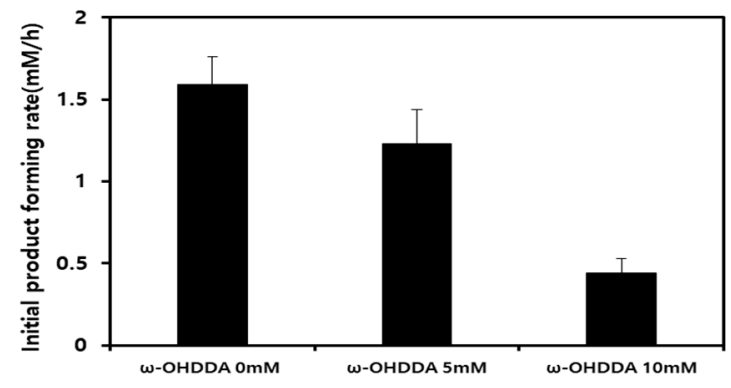

Figure 4. (a) Residual stability of whole cells expressing CYP153AL.m. Reaction conditions: Substrate concentration, $20 \mathrm{mM}$; Volume, $10 \mathrm{~mL}$ in $100 \mathrm{~mL}$ flask; Temp, $30^{\circ} \mathrm{C}$; Cell type, BW25113 ( $\Delta$ fadD, DE3) having CYP153AL.m and CamA/B; Cell OD600, 30; Phosphate buffer, 100 mM; pH, 7.5; glucose 1\% $(w / v)$, The biocatalysts in the each round (every $6 \mathrm{~h}$ ) were re-used in next round, (b) Product inhibited $\omega$-hydroxylation of $20 \mathrm{mM}$ DDA. Reaction condition is the same with $3 \omega$-hydroxylation of $20 \mathrm{mM}$ fatty acids by CYP153A and Cam AB containing cells, Note that: 0,5 and $10 \mathrm{mM}$ of $\omega$-OHDDA was initially added.

Additionally, the residual activity in the third round did not compensate for the product conversion after $12 \mathrm{~h}$ (Figure $2 \mathrm{~b}$ ). We speculate that the phenomenon is caused by product inhibition, which was previously mentioned by Lundemo [23] and the resting cell reaction was carried out in the additional presence of $5 \mathrm{mM}$ and $10 \mathrm{mM} \omega$-OHDDA. The product forming rate significantly decreased 
from $1.59 \pm 0.09 \mathrm{mM} / \mathrm{h}$ to $0.44 \pm 0.17 \mathrm{mM} / \mathrm{h}$ as the initial product concentration increased from 0 to $10 \mathrm{mM}$ (Figure $4 \mathrm{~b}$ ), indicating significant product inhibition. The results of these studies demonstrated that CYP153AL.m three-component system suffered from severe product inhibition, which needs to be overcome to produce high concentrations of the products.

\section{Materials and Methods}

\subsection{Chemicals and Media}

All chemicals, such as DDA, $\omega$-OHDDA, dimethyl sulfoxide (DMSO), isopropyl-thio- $\beta$-D -galactopyranoside (IPTG), 5-aminolevulinic acid (5-ALA), N, O-Bis (trimethylsilyl)-trifluoroacetamide (BSTFA, were purchased from Sigma-Aldrich (St. Louis, MO, USA). Chloroform was obtained from Junsei (Tokyo, Japan). Bacteriological agar, Luria Bertani (LB) broth and terrific broth (TB) media were purchased from BD Difco (Franklin Lakes, NJ, USA). All chemicals used in this study were of analytical grade.

\subsection{Plasmid Construction}

For efficient substrate uptake, IPTG-inducible pCDF_duet1 vector with outer membrane long chain fatty acid (LCFA) transporter, fadL [30] was used. The genes encoding various CYPs were codon-optimized and synthesized from Bionics (Seoul, Korea), before each gene was inserted into the IPTG-inducible pCDF_duet1 vectors using NdeI and $\mathrm{XhoI}$ as a restriction site. For redox partners, CamA (ferredoxin reductase) and CamB (ferredoxin) from Pseudomonas putida and LimA and LimB from Limnobacter sp. MED 105 were cloned into pET_duet1 vector using BamHI \& SacI and NdeI \& EcorV, respectively [30].

\subsection{Protein Expression and Purification}

E. coli BW25113 (DE3) $\Delta$ fadD strain [32] was utilized for the biotransformation studies, wherein the fatty acid degrading $\beta$-oxidation pathway was blocked. Plasmid DNA were transformed into host strains using the standard heat shock method. For the expression and purification of enzymes, fresh colonies from agar plates of transformants were cultured in $2 \mathrm{~mL}$ of LB medium containing appropriate antibiotics at $37^{\circ} \mathrm{C}$ overnight.

The seed-cultured cells were inoculated into $50 \mathrm{~mL}$ of Terrific-Broth (TB) in a 250-mL baffle flask and cultured at $37^{\circ} \mathrm{C}$ until the cell concentration reached an optical density at $600 \mathrm{~nm}\left(\mathrm{OD}_{600}\right)$ of 0.6-0.8 for IPTG induction. The induction was performed by adding $0.01 \mathrm{mM}$ IPTG, $0.25 \mathrm{mM}$ 5-ALA as heme precursor and $0.5 \mathrm{mM} \mathrm{FeSO}_{4}$ at $30^{\circ} \mathrm{C}$ for $16 \mathrm{~h}$. MaqCYP153A, CYP153ALim, CamA/CamB, and LimA/LimB expression were carried out in $1 \mathrm{~L}$ of Terrific-Broth (TB) in a 3-L flask and induction was performed by adding $0.01 \mathrm{mM}$ of IPTG, $0.25 \mathrm{mM}$ 5-ALA as heme precursor and $0.5 \mathrm{mM} \mathrm{FeSO}_{4}$ or only $0.01 \mathrm{mM}$ for the redox-partners at $30^{\circ} \mathrm{C}$ for $16 \mathrm{~h}$. For the purification of enzymes, cells were harvested by centrifugation at $4{ }^{\circ} \mathrm{C}$ and $3000 \mathrm{rpm}$ for $15 \mathrm{~min}$. After this, they were washed and re-suspended in $20 \mathrm{~mL}$ of potassium phosphate buffer $(100 \mathrm{mM}, \mathrm{pH} 7.5)$ before finally being disrupted by sonication.

The soluble fraction of each lysate was collected after centrifugation at 16,000 rpm for $30 \mathrm{~min}$ and the enzymes were purified using a His-Trap- ${ }^{\mathrm{TM}} \mathrm{HP}$ column (GE Healthcare Bio-Sciences AB, Uppsala, Sweden). The Ni-NTA-bound enzymes were washed twice with $50 \mathrm{mM}$ sodium phosphate buffer (pH 8.0) containing $300 \mathrm{mM} \mathrm{NaCl}$ and $20 \mathrm{mM}$ imidazole. Next, the enzymes were eluted out with the same buffer containing $250 \mathrm{mM}$ imidazole. Finally, the purified protein was concentrated by ultra-filtration, before the imidazole and sodium chloride was removed via sequential dialysis. Purified proteins were subjected to SDS-PAGE analysis. 


\subsection{CO-Binding Assay}

The UV absorption spectra of CO-bound recombinant CYP proteins after sodium dithionite reduction were measured by Multi-scan UV-Vis spectrometry (Thermo Fisher Scientific, MA, USA) by scanning wavelengths of $400-500 \mathrm{~nm}$ at intervals of $5 \mathrm{~nm}$. The concentration of P450 was measured using an extinction coefficient of $91.9 \mathrm{mM}^{-1} \mathrm{~cm}^{-1}$ at $450 \mathrm{~nm}$.

\subsection{In-Vitro Oxidation Assay of CYP153As}

The coupling efficiency of each CYPs with a redox partner was evaluated using C12:0 saturated fatty acids as a substrate. The biotransformations were performed using a final volume of $0.5 \mathrm{~mL}$ of $100 \mathrm{mM}$ potassium phosphate buffer (pH 7.5), containing $2 \mu \mathrm{M} \mathrm{CYP153A}$, ferredoxin reductase and ferredoxin i.e., P450, CamA and CamB (1:5:10 ratio) or P450, $\operatorname{LimA}$ and $\operatorname{LimB}$ (1:5:10 ratio) at $25^{\circ} \mathrm{C}$ [28]. Fatty acids were added at a final concentration of $0.5 \mathrm{mM}(25 \mathrm{mM}$ stock in DMSO). The reaction was started by the addition of the $0.2 \mathrm{mM}$ NADH. Furthermore, the consumption of NADH was monitored by measuring absorbance at $340 \mathrm{~nm}\left(\mathrm{e} 340=6.22 \mathrm{mM}^{-1} \mathrm{~cm}^{-1}\right)$. After completion, the reaction was stopped by adding $\mathrm{HCl}$ and samples were analyzed by GC/FID analysis.

\subsection{Resting Cell Reaction}

Cells were harvested by centrifugation and washed with $100 \mathrm{mM}$ potassium phosphate buffer ( $\mathrm{pH} 7.5$ ), followed by resuspension in the same buffer. The cell buffer resuspension was placed into a 100-mL shake flask, with the cell density adjusted to $\mathrm{OD}_{30}$ in the final $10 \mathrm{~mL}$ volume. The resting cell reaction was initiated by adding $20 \mathrm{mM}$ dodecanoic acid (1 M stock in DMSO or powder form). The reactants were incubated at $30^{\circ} \mathrm{C}$ and $200 \mathrm{rpm}$, with $0.5 \mathrm{~mL}$ sample aliquots collected every 2 or $6 \mathrm{~h}$. The sample preparation for product analysis was done as follows: $500 \mu \mathrm{L}$ of the whole cell culture was acidified with $6 \mathrm{M} \mathrm{HCl}$ to a $\mathrm{pH}$ of 2 and extracted with chloroform by vigorous vortexing for $1 \mathrm{~min}$. The organic phases were then collected and derivatized by using trimethylsilyl (TMS) and incubation at $50{ }^{\circ} \mathrm{C}$ for $20 \mathrm{~min}$, with an excess of BSTFA.

\subsection{Product Identification and Quantification}

Quantitative analysis was performed by gas chromatography, HP 6890 Series (Agilent Technologies, Santa Clara, CA, USA) with flame ionization detector (GC/FID). One $\mu \mathrm{L}$ of the sample was injected by the split less mode (a split less time of $0.8 \mathrm{~min}$ ) and analyzed using a nonpolar capillary column ( $5 \%$ phenyl methyl siloxane capillary $30 \mathrm{~m} \times 320 \mu \mathrm{m}$ i.d. $0.25 \mu \mathrm{m}$ film thickness, HP- $5 \mathrm{~ms}$ ).

The oven temperature was maintained at $50^{\circ} \mathrm{C}$ for $1 \mathrm{~min}$, before being increased by $15^{\circ} \mathrm{C} / \mathrm{min}$ to $250{ }^{\circ} \mathrm{C}$, with this temperature held for $10 \mathrm{~min}$. The temperature of the inlet was kept at $250{ }^{\circ} \mathrm{C}$ and the temperature of the detector was $280^{\circ} \mathrm{C}$. The flow rate of the carrier gas was $1.0 \mathrm{~mL} / \mathrm{min}$, while flow rates of hydrogen, air and helium in the FID were 45,400 and $20 \mathrm{~mL} / \mathrm{min}$, respectively. Each peak was identified by comparison of the GC chromatogram with that of an authentic sample. Errors in the analysis were corrected by using heptadecanoic acid as an internal standard.

\section{Concluding Remarks}

This study reports on a $\omega$-hydroxy fatty acid production platform employing efficient CYP153A from Limnobacter sp. MED 105. Furthermore, the application of a powder substrate and introducing a native redox partner was successfully examined in the study. However, product inhibition is a hurdle for the industrial feasibility of this biocatalytic process. In conclusion, with the help of the heterologous expression of novel non-native enzymes in E. coli, we successfully produced $3.28 \mathrm{~g} / \mathrm{L}$ of $\omega$-OHDDA from $4 \mathrm{~g} / \mathrm{L}$ of DDA.

Supplementary Materials: The following are available online at http:/ / www.mdpi.com/2073-4344/9/1/54/s1, Figure S1: Phylogenetic tree used in this study, Figure S2: A SDS-PAGE analysis of protein expression of CYP153As, Figure S3:A CO-binding analysis of CYP153A expressing strains used in this study, Figure S4: An active P450 
concentration used in this study, Figure S5: $\omega$-OHDDA production normalized by amount of active P450s, Figure S6: Protein-protein network of CYP153AL.m(LMED105_04587), Figure S7: SDS-PAGE gel picture of purified protein of CamB (12.75 kDa), CamA (47 kDa), CYP153AM.aq (52.28 kDa), LimB (11.87 kDa), LimA (45.61 kDa), and CYP153AL.m (52.28 kDa).

Author Contributions: H.Y. and B.-G.K. designed the experiments of the project. S.-Y.J. carried out the research works as part of his master's project. H.-W.Y. supervised the whole studies reported in the manuscript. S.-Y.J. and S.S. wrote and revised the manuscript. H.-W.Y. assisted in experimental tools.

Funding: This work was supported by the Ministry of Trade, Industry and Energy of South Korea (MOTIE, Korea) under the industrial Technology Innovation Program (No. 10062550 and 10076343).

Conflicts of Interest: The authors declare no conflict of interest.

\section{Abbreviations}

$\begin{array}{ll}\text { BSTFA } & \text { N, O-bis(trimethylsilyl)trifluoroacetamide } \\ \text { CDW } & \text { cell dry weight } \\ \text { CYP } & \text { cytochrome P450 enzyme } \\ \text { CYP153AL.m } & \text { Limnobacter sp. MED 105 CYP153A } \\ \text { CYP153AM.aq } & \text { Marinobacter aquaeolei CYP153A } \\ \text { CYP153AA.d } & \text { Alcanivorax dieselolei CYP153A } \\ \text { CYP153AS.f } & \text { Solimonas flava CYP153A } \\ \text { DCA } & \text { dicarboxylic acid } \\ \text { DDA } & \text { dodecanoic acid } \\ \text { w-OHDDA } & \text { omega-hydroxydodecanoic acid } \\ \text { OHFAs } & \text { omega-hydroxy fatty acids } \\ \text { TMS } & \text { trimethylsilyl }\end{array}$

\section{References}

1. Soliday, C.L.; Kolattukudy, P.E. Biosynthesis of Cutin $\omega$-Hydroxylation of Fatty Acids by a Microsomal Preparation from Germinating Vicia faba. Plant Physiol. 1977, 59, 1116-1121. [CrossRef] [PubMed]

2. Liu, C.; Liu, F.; Cai, J.; Xie, W.; Long, T.E.; Turner, S.R.; Lyons, A.; Gross, R.A. Polymers from Fatty Acids: Poly ( $\omega$-hydroxyl tetradecanoic acid) Synthesis and Physico-Mechanical Studies. Biomacromolecules 2011, 12, 3291-3298. [CrossRef] [PubMed]

3. Ebata, H.; Toshima, K.; Matsumura, S. Lipase-Catalyzed Synthesis and Properties of Poly[(12-hydroxydodecanoate)-co-(12-hydroxystearate)] Directed Towards Novel Green and Sustainable Elastomers. Macromol. Biosci. 2008, 8, 38-45. [CrossRef] [PubMed]

4. Abe, A.; Sugiyama, K. Growth inhibition and apoptosis induction of human melanoma cells by omega-hydroxy fatty acids. Anti-Cancer Drugs 2005, 16, 543-549. [CrossRef] [PubMed]

5. Bordeaux, M.; Galarneau, A.; Fajula, F.; Drone, J. A Regioselective Biocatalyst for Alkane Activation Under Mild Conditions. Angew. Chem. Int. Ed. Engl. 2011, 50, 2075-2079. [CrossRef] [PubMed]

6. Metzger, J.O.; Bornscheuer, U. Lipids as renewable resources: Current state of chemical and biotechnological conversion and diversification. Appl. Microbiol. Biotechnol. 2006, 71, 13-22. [CrossRef] [PubMed]

7. Yokota, T.; Watanabe, A. Process for Producing Omega-Hydroxy Fatty Acids. U.S. Patent 5191096, 2 March 1993.

8. Labinger, J.A. Selective alkane oxidation: Hot and cold approaches to a hot problem. J. Mol. Catal. A Chem. 2004, 220, 27-35. [CrossRef]

9. Lu, W.; Ness, J.E.; Xie, W.; Zhang, X.; Minshull, J.; Gross, R.A. Biosynthesis of Monomers for Plastics from Renewable Oils. J. Am. Chem. Soc. 2010, 132, 15451-15455. [CrossRef] [PubMed]

10. Scheps, D.; Honda Malca, S.; Richter, S.M.; Marisch, K.; Nestl, B.M.; Hauer, B. Synthesis of $\omega$-hydroxy dodecanoic acid based on an engineered CYP153A fusion construct. Microb. Boithechnol. 2013, 6, 694-707. [CrossRef] [PubMed]

11. Funhoff, E.G.; Salzmann, J.; Bauer, U.; Witholt, B.; van Beilen, J.B. Hydroxylation and epoxidation reactions catalyzed by CYP153 enzymes. Enzyme Microb. Technol. 2007, 40, 806-812. [CrossRef]

12. Scheps, D.; Malca, S.H.; Hoffmann, H.; Nestl, B.M.; Hauer, B. Regioselective w-hydroxylation of medium-chain n-alkanes and primary alcohols by CYP153 enzymes from Mycobacterium marinum and Polaromonas sp. strain JS666. Org. Biomol. Chem. 2011, 9, 6727-6733. [CrossRef] [PubMed] 
13. Narhi, L.O.; Fulco, A.J. Identification and Characterization of Two Functional Domains in Cytochrome P-450BM-3, a Catalytically Self-sufficient Monooxygenase Induced by Barbiturates in Bacillus megaterium. J. Biol. Chem 1987, 262, 6683-6690. [PubMed]

14. Malca, S.H.; Scheps, D.; Kühnel, L.; Venegas-Venegas, E.; Seifert, A.; Nestl, B.M.; Hauer, B. Bacterial CYP153A monooxygenases for the synthesis of omega-hydroxylated fatty acids. Chem. Commun. 2012, 48, 5115-5117. [CrossRef] [PubMed]

15. Zhang, T.; Wei, D.-Q. Recent Progress on Structural Bioinformatics Research of Cytochrome P450 and Its Impact on Drug Discovery. Adv. Struct. Eng. 2015, 827, 327-339.

16. Darabi, M.; Seddigh, S.; Abarshahr, M. Structural, functional, and phylogenetic studies of cytochrome P450 (CYP) enzyme in seed plants by bioinformatics tools. Caryologia 2017, 70, 62-76. [CrossRef]

17. Fischer, M.; Knoll, M.; Sirim, D.; Wagner, F.; Funke, S.; Pleiss, J. The Cytochrome P450 Engineering Database: A navigation and prediction tool for the cytochrome P450 protein family. Bioinformatics 2007, 23, $2015-2017$. [CrossRef]

18. Ma, Q.H.; Tian, B. Biochemical characterization of a cinnamoyl-CoA reductase from wheat. Biol. Chem. 2005, 386, 553-560. [CrossRef]

19. von Bühler, C.; Le-Huu, P.; Urlacher, V.B. Cluster Screening: An Effective Approach for Probing the Substrate Space of Uncharacterized Cytochrome P450s. ChemBioChem 2013, 14, 2189-2198. [CrossRef]

20. Donova, M.V.; Nikolayeva, V.M.; Dovbnya, D.V.; Gulevskaya, S.A.; Suzina, N.E. Methyl-beta-cyclodextrin alters growth, activity and cell envelope features of sterol-transforming mycobacteria. Microbiology 2007, 153, 1981-1992. [CrossRef]

21. Kühnel, K.; Maurer, S.C.; Galeyeva, Y.; Frey, W.; Laschat, S.; Urlacher, V.B. Hydroxylation of Dodecanoic Acid and $(2 R, 4 R, 6 R, 8 R)$-Tetramethyldecanol on a Preparative Scale using an NADH-Dependent CYP102A1 Mutant. Adv. Synth. Catal. 2007, 349, 1451-1461. [CrossRef]

22. Rammler, D.H.; Zaffaroni, A. Biological implications of DMSO based on a review of its chemical properties. Ann. N. Y. Acad. Sci. 1967, 141, 13-23. [CrossRef] [PubMed]

23. Lundemo, M.T.; Notonier, S.; Striedner, G.; Hauer, B.; Woodley, J.M. Process limitations of a whole-cell P450 catalyzed reaction using a CYP153A-CPR fusion construct expressed in Escherichia coli. Appl. Microbiol. Biotechnol. 2016, 100, 1197-1208. [CrossRef] [PubMed]

24. Rimal, H.; Lee, S.W.; Lee, J.H.; Oh, T.J. Understanding of real alternative redox partner of Streptomyces peucetius DoxA: Prediction and validation using in silico and in vitro analyses. Arch. Biochem. Biophys. 2015, 585, 64-74. [CrossRef] [PubMed]

25. Lin, B.; Tao, Y. Whole-cell biocatalysts by design. Microb. Cell Fact. 2017, 16, 106. [CrossRef] [PubMed]

26. Wachtmeister, J.; Rother, D. Recent advances in whole cell biocatalysis techniques bridging from investigative to industrial scale. Curr. Opin. Biotechnol. 2016, 42, 169-177. [CrossRef] [PubMed]

27. Zhang, W.; Du, L.; Li, F.; Zhang, X.; Qu, Z.; Han, L.; Li, Z.; Sun, J.; Qi, F.; Yao, Q.; et al. Mechanistic Insights into Interactions between Bacterial Class I P450 Enzymes and Redox Partners. ACS Catal. 2018, 8, 9992-10003. [CrossRef]

28. Pandey, B.P.; Lee, N.; Choi, K.Y.; Kim, J.N.; Kim, E.J.; Kim, B.G. Identification of the specific electron transfer proteins, ferredoxin, and ferredoxin reductase, for CYP105D7 in Streptomyces avermitilis MA4680. Appl. Microbiol. Biotechnol. 2014, 98, 5009-5017. [CrossRef] [PubMed]

29. Szklarczyk, D.; Morris, J.H.; Cook, H.; Kuhn, M.; Wyder, S.; Simonovic, M.; Santos, A.; Doncheva, N.T.; Roth, A.; Bork, P.; et al. The STRING database in 2017: Quality-controlled protein-protein association networks, made broadly accessible. Nucleic. Acids Res. 2017, 45, D362-D368. [CrossRef] [PubMed]

30. Jung, E.; Park, B.G.; Ahsan, M.M.; Kim, J.; Yun, H.; Choi, K.Y.; Kim, B.G. Production of w-hydroxy palmitic acid using CYP153A35 and comparison of cytochrome P450 electron transfer system in vivo. Appl. Microbiol. Biotechnol. 2016, 100, 10375-10384. [CrossRef] [PubMed] 
31. Bernhardt, R.; Urlacher, V.B. Cytochromes $\mathrm{P} 450$ as promising catalysts for biotechnological application: Chances and limitations. Appl. Microbiol. Biotechnol. 2014, 98, 6185-6203. [CrossRef] [PubMed]

32. Bae, J.H.; Park, B.G.; Jung, E.; Lee, P.-G.; Kim, B.-G. fadD deletion and fadL overexpression in Escherichia coli increase hydroxy long-chain fatty acid productivity. Appl. Microbiol. Biotechnol. 2014, 98, 8917-8925. [CrossRef] [PubMed]

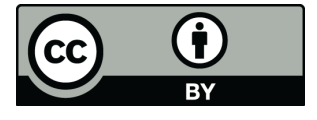

(C) 2019 by the authors. Licensee MDPI, Basel, Switzerland. This article is an open access article distributed under the terms and conditions of the Creative Commons Attribution (CC BY) license (http:/ / creativecommons.org/licenses/by/4.0/). 